\title{
THE ROLE OF THE XAVANTE INDIGENOUS PEOPLE IN WILDLIFE CONSERVATION
}

\author{
O PAPEL DO POVO INDÍGENA XAVANTE NA CONSERVAÇÃO DA VIDA \\ SIL VESTRE
}

Manrique Prada* ${ }^{1 \star}$ Paulo Cipassé Xavante ${ }^{2}$

\begin{abstract}
:
There is an urgent demand to evaluate and document the environmental conditions of the territories of indigenous people. This is basic in the efforts to achieve sustainable development goals adopted by all United Nations Member States in 2015. The Xavante people are hunters/gatherers and depend on natural resources for their physical, spiritual, and cultural survival. Their lands are localized in the state of Mato Grosso, Brazil, in a transitional area between the Cerrado vegetation and the Amazon rainforest. They have been developing environmental projects in order to manage their territory correctly for decades, as part of their survival strategy. In recent fieldwork, we stated that some major game species may still be abundant in the territory and we suggest that certain wildlife management measures in the past may be responsible for this. We easily registered most game species handled by the Xavantes, except for some edentates that were rarely detected. We confirm the giant anteater as the most vulnerable species to hunting effects. In this article, we point out the main threats for the territory and present new recommendations that may be fundamental for the conservation of biodiversity in the region and the survival of the Xavante people.
\end{abstract}

Keywords: Brazil; hunting; sustainability; traditional knowledge; wildlife management.

\section{Resumo:}

Existe uma demanda urgente de avaliar e documentar as condições ambientais dos territórios indígenas. Isso é básico nos esforços para atingir as metas de desenvolvimento sustentável, adotadas por todos os Estados Membros das Nações Unidas em 2015. O povo Xavante tradicionalmente é de caçadores/coletores e dependem dos recursos naturais para sua sobrevivência física, espiritual e cultural. Suas terras estão localizadas no estado de Mato Grosso, em uma área de transição entre a vegetação do Cerrado e a floresta amazônica. Há décadas que desenvolvem projetos

\footnotetext{
${ }^{1}$ Travessa Konzen, No 82, Bairro Xavantina Velha, Nova Xavantina, Mato Grosso, Brazil.

${ }^{2}$ Associação Aliança dos Povos do Roncador, Água Boa, Mato Grosso, Brazil.

* Contato para correspondência: manriquepradavillalobos@gmail.com
} 
ambientais para tentar manejar seu território de maneira correta, como parte de sua estratégia de sobrevivência. Algumas espécies importantes de caça ainda são abundantes no território e sugerimos que certas medidas de manejo de fauna no passado podem ser responsáveis por isso. Registramos facilmente a maioria das espécies cinegéticas utilizadas pelos Xavantes, com exceção de alguns edentados que raramente foram detectados. Confirmamos o tamanduá-bandeira como a espécie mais vulnerável aos efeitos da caça. Apontamos as principais ameaças ao território e apresentamos novas recomendações que podem ser fundamentais para a conservação da biodiversidade na região e para a sobrevivência do povo Xavante.

Palavras-chave: Brasil; caça; conhecimento tradicional; manejo de fauna; sustentabilidade.

\section{Introduction}

It is known that formally protected areas and global targets for conservation are not enough to stem current threats to biodiversity and achieve the sustainable development goals adopted by all United Nations Member States in 2015. There is a need to include indigenous territories and other community-protected lands in order to better approach that task (CORRIGAN et al., 2018, THIEDE AND GRAY, 2020). This is fundamental because indigenous peoples manage over a quarter of the world's land surface, representing about $40 \%$ of all terrestrial protected areas and natural landscapes (GARNETT et al., 2018). Specifically, in Latin America, there is an urgent demand to evaluate and document the environmental conditions of the indigenous peoples' territories. There is evidence indicating that indigenous-managed lands can contribute significantly to biodiversity conservation. For example, in Brazil, it has been attested that indigenous territories were slightly more vertebrate species-rich than existing protected areas (SCHUSTER et al., 2019). For these reasons, efforts to support and encourage environmental studies in indigenous lands are well justified, especially those located in ecological relevant areas and endangered ecosystems.

The Xavantes are hunters/gatherers and depend on wildlife for their physical, spiritual, and cultural survival (MAYBURY-LEWIS, 1984). As in other natural resource-dependent communities, there is a strong interest within the Xavante community to maintain their food sources. Since the first contact in the decade of the 1940s and after many years of persecution, they started negotiating with the warazu (non-indigenous) for the recognition of their lands. They knew that this was mandatory to guaranteeing their survival, maintaining their culture, and their spirituality, all strongly linked together with nature. Thus, the Xavantes also understood that they urgently needed to stop the warazu processes and activities responsible for the destruction of the Cerrado vegetation. Traditionally, the Xavante people is seminomadic hunter-gatherers who once exploited a large territory (GRAHAM, 2000). In the past, when they felt that natural resources were becoming scarce they moved to other areas returning only after a long time. By doing that, resources were never totally depleted and the areas eventually recovered. After the first contact and with an intensely expanding Brazilian frontier, their seminomadic lifestyle became inviable. They were forced by the government to stay within a limited area and to abandon their traditional way of managing natural resources. 


\subsection{The Xavante strategy}

In the 1970s, the Xavante chief Apowe had a vision through a dream and proposed to his people that they should send a group of young boys to study outside the territory. These young boys were supposed to learn from the non-indigenous society so they could be able to negotiate in the future. They were also meant to make contacts with other indigenous and with organizations that could support them. For the Xavante people, dreams are extremely important and many decisions of the community are taken based on a dreamer's narrative (GRAHAM, 1995). The community followed Apowe's dream and decided to send their children to Ribeirão Preto and Goiania in the states of São Paulo and Goiás. Later on, in the 1980s, Sibupá (son of Apowe) envisioned in another dream the diminishing of game animals in their lands and stated the necessity of non-indigenous help for solving this problem. The young men that were living in the city were alerted, so they contacted The Center of Indigenous Research (CPI), Brazil's Union of Indigenous Nations (UNI), and the University of Goiás State (UCG). These organizations supported them by writing the Jaburu Project and contacting financial sources. This was the beginning of a series of environmental projects that were developed in the Pimentel Barbosa Territory, combining scientific methodology and traditional knowledge. As a result, important scientific publications that discuss relevant ecological aspects have been generated (FRAGOSO et al., 2000; GRAHAM, 2000; LEEUWENBERG AND ROBINSON, 2000; PRADA, 2001; PRADA AND MARINHO-FILHO, 2004; WELCH et al., 2013a; WELCH, 2014, 2015). For many years and various generations, new ideas and discussions about land management and conservation have been a central issue for the Xavante people. This has changed their traditional view and their concepts related to the environment, resource availability, and biogeography. Over time, cultural changes have been so profound that they have been embedded in the dreams of Xavante visionary leadership, therefore being passed on to new generations.

The objective of this study was to examine the current situation of wildlife in the Pimentel Barbosa Territory through a comparative approach with data collected at the end of the last century. We wanted to discuss the relevance and effectiveness of some of the management measurements that were suggested in the past taking into consideration the opinion of experienced Xavante hunters. We also wanted to point out the main threats for the Territory and deliberate on some ideas that can help the Xavante people achieve their conservation goals.

\section{Material and Methods}

The Xavante people live in the state of Mato Grosso, in a transitional area between a drier, more opened Cerrado vegetation, and the Amazon rainforest in Central Brazil (Figure 1). 


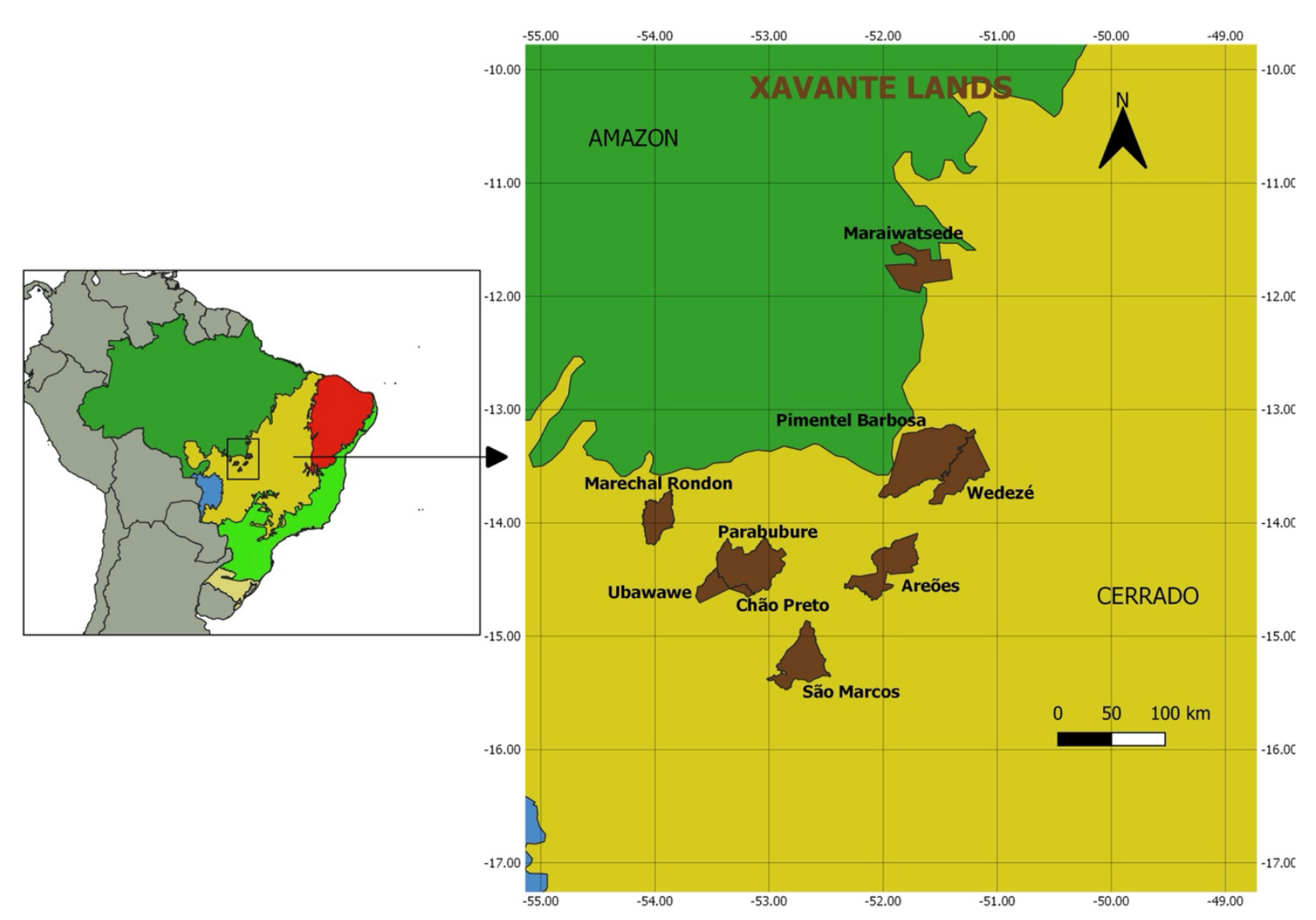

Figure 1: Localization of the Xavante lands in Brazil and the Pimentel Barbosa Territory in the Cerrado/Amazon transition. Source: Authors.

Their population sums up more than 18.214 individuals distributed in ten indigenous territories (SIASI/SESAI, 2014). The Pimentel Barbosa Territory has an area of 328.966 ha with approximately 4000 Xavantes living in 16 villages. The climate is characterized by a hot rainy season from October to April and a colder dry season from May to September. The drier season favors the occurrence of wildfires and it is the time for the Xavante fire hunts (PRADA, 2001; PRADA AND MARINHO-FILHO, 2004; WELCH et al., 2013b; WELCH, 2014, 2015; WELCH AND COIMBRA, 2019). Approximately, two-thirds of the Pimentel Barbosa Indigenous Territory have a flat and regular topography and there is also a portion of rocky slopes and the tops of Serra do Roncador. This mountain range is the last remnant of a plateau that separates the Xingu Basin from the Rio das Mortes Basin, representing an important structural and geotectonic limit in Brazil (ALMEIDA AND HENNIES, 1969). The Pimentel Barbosa Indigenous Territory has a high diversity of habitats and species (FRAGOSO et al., 2000; WELCH et al., 2013b). One of the reasons is the localization in a transitional area that permits species of open and forested areas to occur together. The vegetation within the territory consists of a mixture of cerrado vegetation, natural grasslands, riparian forests, gallery forests, seasonally flooded forest fragments (known locally as "impucas"), and patches of dry forest. Approximately onethird of the territory is made up of open areas, partially flooded during the rainy season. It is a very well-drained area with large rivers such as the Rio das Mortes, which contributes significantly to the high diversity of fish (MELO et al., 2007), reptiles (NOGUEIRA et al., 2010), birds (SICK, 1985), and mammals. The most important animals which serve as food for the Xavantes are medium and large-sized mammals. Within 
this group, white-lipped peccary (Tayassu pecarl), collared peccary (Pecari tajacu), tapir (Tapirus terrestris), marsh deer (Blastocerus dichotomus), pampas deer (Ozotoceros bezoarticus), red-brocket deer (Mazama americana), grey-brocket deer (Mazama gouazoubira), giant anteater (Myrmecophaga tridactyla) and giant armadillo (Priodontes maximus) are appreciated as game species. Peccaries were the most frequently hunted animals in the territory, according to studies carried out at the end of the last century (FRAGOSO et al., 2000; LEEUWENBERG AND ROBINSON, 2000).

During recent fieldwork, we collected some data on the situation of the major game species in the area of the Wederã Village. The community of the Wederã Village utilizes an area of approximately 80,000 ha and it is located in the northern portion of the territory. This area, in particular, was studied in the past century by Fragoso et al., (2002) and Leeuwenberg and Robinson, (2000). We covered $1200 \mathrm{~km}$ by motorcycle and visited 21 sites chosen previously by the Xavante community as important places in terms of natural resources. In these sites, we tracked during one hour and registered the presence of the main game species. The searching and identification of animal tracks have been executed with Xavantes' help and experience. In the case of collared peccaries, we used a standardized value that was registered based on relative abundance, with 1 = few tracks, $11=$ a median number of tracks, and $21=$ many tracks. For the white-lipped peccary the standardized values were 1, 31, and 51, also corresponding to a small, medium, and a large number of tracks, respectively. We decided to do this because of excessive track overlapping that makes it impossible to individualize peccary tracks. All animal sightings were recorded while traveling by motorcycle and when tracking on foot. The distances from the observer to the animal, habitat type, and the individuals' sex were registered when possible. We also gathered information (during 3 months) on the total number of hunted animals killed by the Xavantes in the Territory.

\section{Results and Discussion}

\subsection{Evaluation of wildlife}

\subsubsection{Tracks and animal sightings}

Certain game species commonly occurred in the 21 sites visited (Figure 2) and large mammals like peccaries, pampas deer, and tapir were easily sighted within the Pimentel Barbosa territory (Table 1). We found few tracks of large edentates, especially the giant anteater, that have been considered the most vulnerable species by FRAGOSO et al., (2000). The jaguar (Panthera onca) was spotted once near a group of white-lipped peccaries and has been easily tracked within the study area (Table 1). 


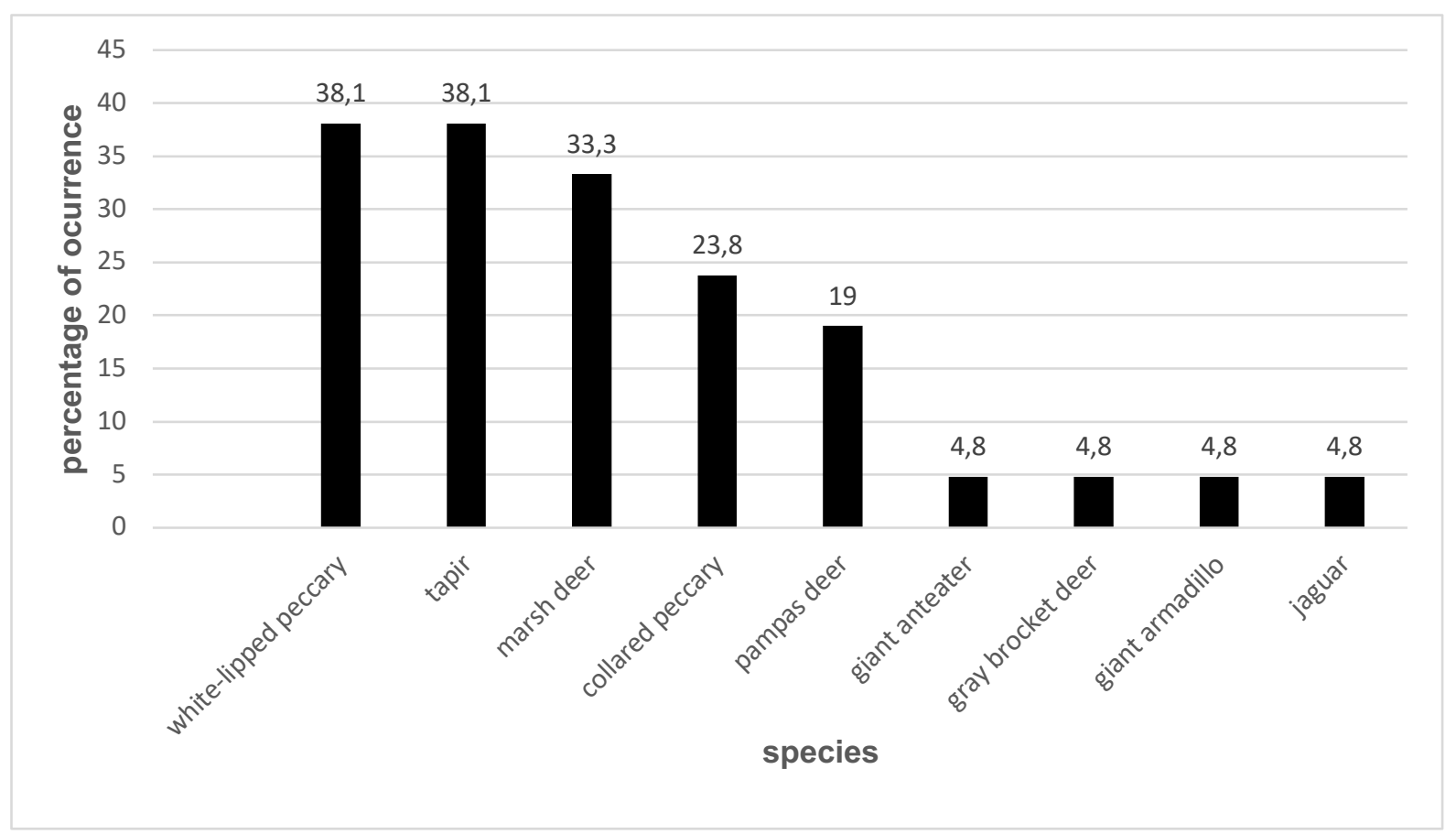

Figure 2: Percentage of occurrence of large mammals on the 21 sites visited at the Pimentel Barbosa Territory. Fonte: autoria própria. Source: Authors.

Top predators, like other large carnivores, are potentially affected by anthropogenic disturbances, climate changes, habitat, vegetation, preys distribution, and competitors (QI et al., 2020). In this way, the constant presence of the jaguar (and its preys) in the Territory may be interpreted as a sign of ecological integrity and natural system functionality. In the past century, Fragoso et al., (2000) considered the jaguar to be rare in the territory, and during ninety days of fieldwork, this species was never spottedand could be tracked only twice. At that time, animal sightings were so scarce that Fragoso et al., (2000) had to change the methodology from censusing individuals (by visualization) to counting animal tracks. At the end of their fieldwork, they had covered at least $1280 \mathrm{~km}$ by car and $768 \mathrm{~km}$ (approximately 192 hours) of walked transects and no jaguar, tapir, or white-lipped peccaries have been detected.

Table 1: The number of animal sightings, tracks, and the total number of hunted animals registered in Pimentel Barbosa Territory. + = standard deviation.

\begin{tabular}{cccc}
\hline Species & Sightings & Tracks & Hunted \\
white-lipped peccary & 40 & $10.95 \pm 16.09$ & 16 \\
pampas deer & 11 & $0.48 \pm 1.12$ & 5 \\
collared peccary & 6 & $3.14 \pm 7.81$ & 4 \\
tapir & 5 & $2.09 \pm 3.08$ & 0 \\
marsh deer & 3 & $0.52 \pm 0.87$ & 1 \\
gray brocket deer & 2 & $0.09 \pm 0.44$ & 0 \\
jaguar & 1 & $0.14 \pm 0.36$ & 0 \\
giant anteater & 0 & $0.48 \pm 0.218$ & 1 \\
giant armadillo & 0 & $0.14 \pm 0.36$ & 0 \\
\hline
\end{tabular}




\subsubsection{Hunted animals}

Six species of large mammals were hunted in the study area by the Xavantes during our fieldwork (Table 1). This represents $60 \%$ of the total number of medium and large mammal species registered by Leeuwenberg and Robinson (2000) in their study. The number of hunted species and individuals is considerably high, taking into account the long hunting history in the region, the Xavante population increase, our sample size, and the fact that we collected data in the rainy season when it is known that Xavantes hunt less (Table 1). Two decades ago, higher numbers of hunt animals were registered (except for white-lipped peccaries in 1992), however the study, made by Leeuwenberg and Robinson (2000), took samples during three consecutive years, including during the dry season, when fire hunts occur and generally a larger number of animals are killed.

\subsubsection{Species conservation status}

Based on tracks, sightings, and hunting evidence we continue to consider the giant anteater as the most vulnerable species in the Territory, as already pointed out by Fragoso et al. (2000). We found a few signs while tracking and even if one individual has been hunted, no other has been spotted. The giant anteater is slow, easily spotted, and killed in open areas, where he frequently forage termites (PRADA, 2004). Another species that raises concern is the pampas deer since all of the killed animals were females. Pronounced sex ratio distortions in a deer population may be due to overhunting as discussed by Fragoso et al., (2000). We also consider that peccaries, tapirs, marsh deer, and other species are of less concern, however, there is an urgent need for a permanent and continuous monitoring program for all the game species in the Pimentel Barbosa Territory. Members of the Xavante community have the will to do so and are already capable of managing this task with little external dependence.

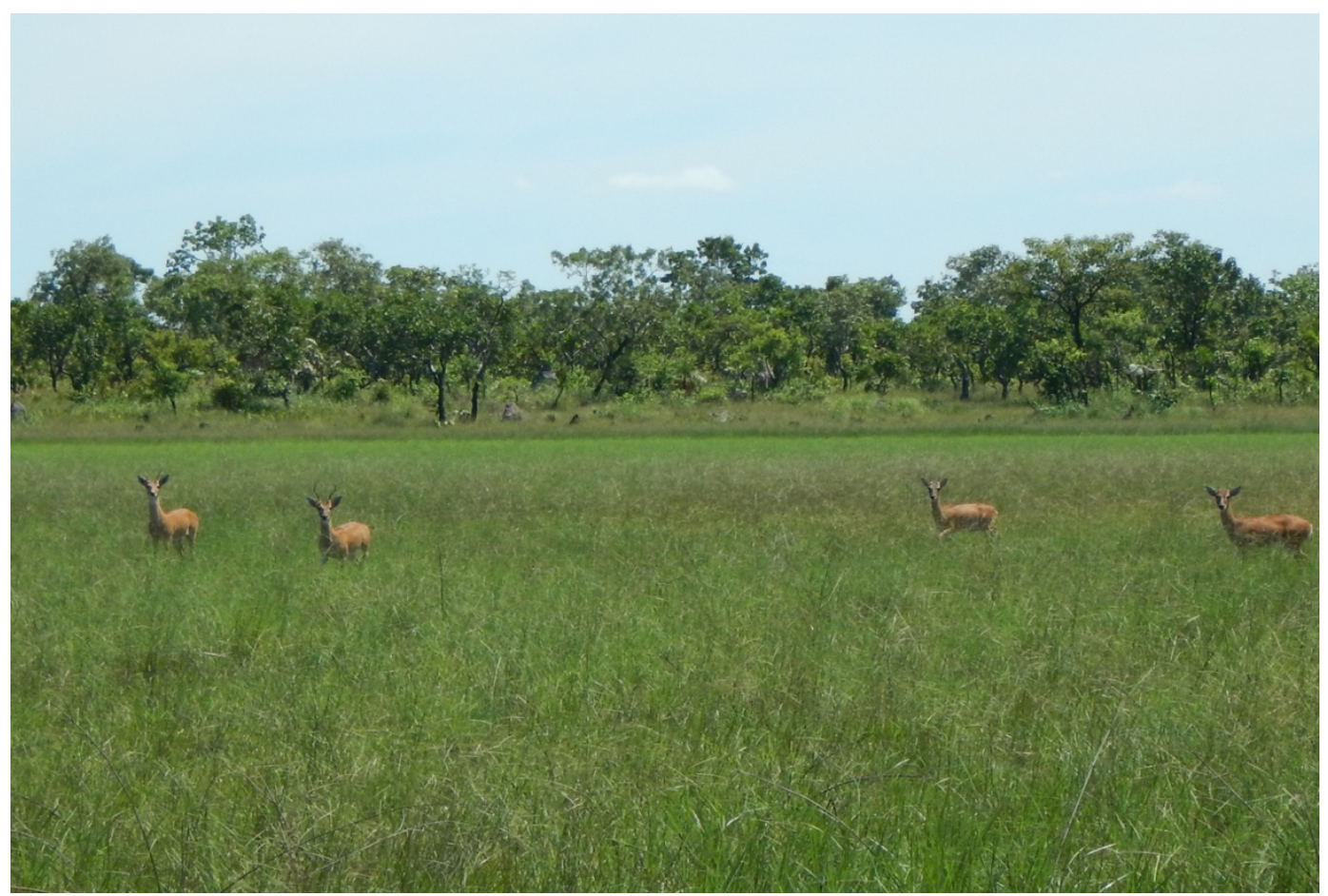

Figure 3: Pu’Wawe. Source: Pontal Sereuwazaowe Xavante. 


\subsubsection{Traditional knowledge and sustainable hunting}

We talked to at least seven experienced hunters in the study area regarding the abundance of animals and they all agreed about the high number of game species, including giant anteater and pampas deer, in the Territory. For the Xavante hunters, the wildlife management project refuges recommended by Fragoso et al., (2000) may be an explanation for the apparent increase in wildlife abundance. They argue that refuges serve as reproduction areas where animals can multiply and then migrate when the sites become crowded. They refer to the refuges as the "the villages of the animals where they can reproduce". The idea of refuges was very well assimilated by the Xavantes and can be considered one of the most important management measurements recommended at the end of the last century by Fragoso et al., (2000). If the refuges truly have contributed to the maintenance of wildlife within the territory, then the Xavantes have been sustainably using their natural resources (in this case animals) by adopting a management strategy that guarantees the maintenance of wildlife. It is relevant to mention that Fragoso's conservation measurement at a landscape level (refuges) made more sense to the Xavantes than any other conservation measurement made at a species level, like banning hunting on determined animals.

Other possible factors that we believe could have also contributed to a possible increase in wildlife other than the refuges are 1) a decrease of hunting pressure due to greater consumption and dependence on industrialized food 2) an increase in animal densities due to deforestation in natural areas outside the territory 3) removal of cattle from some parts of the territory as recommended by biologists in the 1990s and 4) recovery of degraded areas near the old UTA farm within the territory as suggested by biologists in the 1990s.

\subsection{Threats to Biodiversity}

The Pimentel Barbosa Indigenous Territory is located in a critical transitional area between the Cerrado and the Amazon, where it has been historically under pressure from cattle and soy producers. The increase in deforestation closer to the Territory is augmenting near the rivers that serve as geographical limits (Rio Corixão, Rio das Mortes, Rio Agua Suja) and proximate to the federal highway. The territory is increasingly being surrounded by plantations, augmenting its degree of isolation and creating greater vulnerability to edge effects. Isolation due to agricultural and livestock expansion may be the main threats to biodiversity in the Pimentel Barbosa Territory. Besides, the proximity of growing cities and municipalities together with its road network augments the pressure on the Xavante lands. Fragoso et al., (2000) assumed in their management plan that the refuges recommended could supply the Xavante hunting demands even with a population increase. We believe that the three refuges proposed by Fragoso et al., (2000) are not enough since the Xavante population in the Pimentel Barbosa Territory went from 714 to 4000 individuals in 20 years. Another problem with the refuges (sources) is that they are located within the territory and have a limited size.

We suggest the incorporation of 100.000 ha near the northwestern limit of the territory (including the old Sorepré Village) to offset deforestation, agricultural expansion, and 
the isolation of Xavante lands. According to the Xavantes, the Sõrepré Village marks an important milestone in their history (GRAHAM, 1995). This new area should be connected through an ecological corridor to the Araguaia State Park, including the southern limits of three fragments that were considered as priorities for biodiversity conservation by the Environmental Ministry of Brazil (BRASIL, 2017). This connection can be made by including the springs of River São João Grande and following this watercourse to his encounter with the Rio das Mortes. In this way, the Araguaia State Park will become the source of a meta-population system with the possibility, if necessary, of naturally recharging (with plants and animals) the former refuges in the future. We believe that the expansion of the territory and its connectivity with other natural areas are necessary for the conservation of wildlife and the cultural maintenance of the Xavante people. It guarantees food security and the possibility of developing sustainable activities for future generations. A major threat to this recommendation is the construction of the highway BR 080 that is meant to cut across this area and will pass at just $13 \mathrm{~km}$ from the Pimentel Barbosa Territory. Its environmental and cultural impacts on the Xavante people are inestimable and some of them may be irreversible.

\section{Conclusions}

The Xavantes continue to hunt the same species that their ancestors used to. They have been able to maintain their natural resources and none of the species have suffered local extinction. The composition of the main hunting species has not changed and the presence of important top predators, fruit-eaters, and large herbivores can be stated. Within the Territory, there are no major changes in vegetation and some places visited in 2020 are even better than in the 1990s. We believe that the key to the conservation of these lands has been the presence of the Xavantes with their profound connection with nature.

The Cerrado is an important type of vegetation and even though it is considered a world hotspot of biodiversity (MYERS et al., 2000), 50\% of the biome have already disappeared (FRANÇOSO et al., 2015). Taking this into consideration, we should be grateful to the Xavante people for their immense contribution to the conservation of one of the largest continuous fragments of this threatened biome. It is our responsibility to encourage and support them in their struggle to protect the biodiversity present in their lands.

\section{Acknowledgments}

To the Xavante people for their sympathy and hospitality.

\section{References -}

ALMEIDA, F.F.M; HENNIES, W.T. Reconhecimento geológico da Serra do Roncador, Estado de Mato Grosso. Boletim da sociedade brasileira de Geologia, São Paulo, v.18, n.1, p. 23-30, 1969. 
BRASIL - Ministério de meio ambiente, Áreas Prioritárias para Conservação da Biodiversidade Brasileira, Brasília, DF, 2017, Available at: http://areasprioritarias.mma.gov.br/. Access in: $28 \mathrm{Jul} 2020$.

CORRIGAN, C.; BINGHAM, H.; SHI, Y.; LEWIS, E.; CHAUVENET, A.; KINGSTON, N. Quantifying the contribution to biodiversity conservation of protected areas governed by Indigenous peoples and local communities. Biological Conservation, v. 227, p. 403412, 2018. Available at: https://doi.org/10.1016/j.biocon.2018.09.007. Access in: 03 Sep. 2019.

FRAGOSO, J.M.; SILVIUS, K.M.; PRADA, M. Manejo de Fauna na Reserva Xavante Rio das Mortes, MT: Cultura Indígena e Método Científico Para Conservação. World Wildlife Fund, 2000. 65 p.

FRANÇOSO, R.D.; BRANDÃO, R.; NOGUEIRA, C.C.; SALMONA, Y.B.; MACHADO, R.B.; COLLI, G.R. Habitat loss and the effectiveness of protected areas in the Cerrado Biodiversity Hotspot. Natureza e Conservação, v. 13, n.1, 35-40. 2015. Available at: https://doi.org/10.1016/j.ncon.2015.04.001. Access in: 01 Sep. 2019.

GARNETT, S.T.; BURGESS, N.D.; FA, J.E.; FERNÁNDEZ-LLAMAZARES, Á.; MOLNÁR, Z; ROBINSON, C.J.; WATSON, J.E.M.; ZANDER, K.K.; AUSTIN, B.; BRONDIZIO, E.S.; COLLIER, N.F.; DUNCAN, T.; ELLIS, E.; GEYLE, H.; JACKSON, M.V.; JONAS, H.; MALMER, P.; MCGOWAN, B.; SIVONGXAY, A.; LEIPER, I. A spatial overview of the global importance of Indigenous lands for conservation. Nature Sustainability 1: 369-374. 2018. Available at: https://doi.org/10.1038/s41893-018-0100-6. Access in: 03 Oct. 2019.

GRAHAM, L.R. Lessons in Collaboration: The Xavante/WWF Wildlife Management Project in Central Brazil. In: WEBER, R.; BUTLER, J.; LARSON, P. Indigenous Peoples and Conservation Organizations: Experiences in Collaboration. Washington DC: World Wildlife Fund, 2000. p. 47-71.

GRAHAM, L.R. Performing dreams: Discourses of Immortality Among the Xavante of Central Brazil. Austin: University of Texas Press, 1995. 290 p.

LEEUWENBERG, F.; ROBINSON, G. Traditional Management of Hunting by a Xavante Community in Central Brazil: The Search for Sustainability. In: ROBINSON, G.; BENNETT, E.L. Hunting for Sustainability in Tropical Forests. New York: Columbia University Press, 2000. p. 375-394.

MAYBURY-LEWIS, D. A sociedade Xavante. Rio de Janeiro: Livraria Alves, 1984. p.400.

MELO, T.L.; TEJERINA-GARRO, F.L.; MELO, C.E. Diversidade biológica da comunidade de peixes no baixo Rio das Mortes, Mato Grosso, Brasil. Revista Brasileira de Zoologia 24: 657-665. 2007. Available at: http://dx.doi.org/10.1590/S0101-81752007000300017. Access in: 01 Dec. 2020.

MYERS, N; MITTERMELER, A. R.; MITTERMELER, C. G.; FONSECA, G.B.A.; KENT, J. Biodiversity hotspots for conservation priorities. Nature, London, v. 403, n. 6772, p. 853858,2000

NOGUEIRA, C.; COLLI, G.; COSTA, G.; MACHADO, R. Diversidade de répteis Squamata e evolução do conhecimento faunístico no Cerrado. In: DINIZ, I.R.; MARINHO-FILHO, J.; MACHADO, R.B.; CAVALCANTI, R.B. Cerrado Conhecimento Científico Quantitativo Como Subsídio Para Ações de Conservação. Brasília: Thesaurus, 2010. p. 333-375. 
PRADA, M. Effects of fire on the abundance of large mammalian herbivores in Mato Grosso, Brazil. Mammalia, Paris, v. 65, n.1, p. 55-62, 2001.

PRADA, M.; MARINHO-FILHO, J. Effects of fire on the abundance of Xenarthrans in Mato Grosso, Brazil. Austral ecology, Windsor, v. 29, n.5, p. 568-573, 2004.

QI, J.; HOLYOAK, M.; NING, Y.; JIANG, G. Ecological thresholds and large carnivores conservation: Implications for the Amur tiger and leopard in China. Global Ecology and Conservation. 2020. Available at: https://doi.org/10.1016/j.gecco.2019.e00837. Access in: 23 Feb. 2020.

SCHUSTER, R.; GERMAIN, R.R.; BENNETT, J.R.; REO, N.J.; ARCESE, P. Vertebrate biodiversity on indigenous-managed lands in Australia, Brazil, and Canada equals that in protected areas. Environmental Science and Policy. v. 101, p. 1-6. 2019. Available at: https://doi.org/10.1016/j.envsci.2019.07.002. Access in: 23 Feb. 2020.

SIASI/SESAI - Povos Indígenas no Brasil, Brasília, 2014, Available at: https://pib.socioambiental.org/pt/. Quadro Geral dos Povos. Access in: 24 Apr. 2020.

SICK, H. Ornitologia brasileira: uma introdução. Brasília: Universidade de Brasília, 1985. $862 \mathrm{p}$.

THIEDE, B.C.; GRAY, C. Characterizing the indigenous forest peoples of Latin America: Results from census data. World Development, v. 125, p. 104685, 2020. Available at: https://doi.org/10.1016/j.worlddev.2019.104685. Access in: 19 Mar. 2020.

WELCH, J.R. Learning to Hunt by Tending the Fire: Xavante Youth, Ethnoecology, and Ceremony in Central Brazil. Journal of Ethnobiology v. 35, n.1, p. 183-208. 2015. Available at: https://doi.org/10.2993/0278-0771-35.1.183. Access in: 20 Mar. 2020.

WELCH, J.R. Xavante Ritual Hunting: Anthropogenic Fire, Reciprocity, and Collective Landscape Management in the Brazilian Cerrado. Human Ecology, v. 42, n.1, p. 47-59. 2014. Available at: https://10.1007/s10745-013-9637-1. Access in: 22 Mar. 2020.

WELCH, J.R.; BRONDÍZIO, E.S.; HETRICK, S.S.; COIMBRA, C.E. Indigenous burning as conservation practice: neotropical savanna recovery amid agribusiness deforestation in Central Brazil. PLoS One, v. 8, n. 12, p. e81226. 2013a. Available at: https://doi.org/10.1371/journal.pone.0081226. Access in: 22 Mar. 2020.

WELCH, J.R.; SANTOS, R.V.; FLOWERS, N.M.; COIMBRA, C.E.A. Na primeira margem do rio: território e ecologia do Povo Xavante de Wedezé. Rio de Janeiro: Museu do Índio/FUNAI, 2013b. 210 p.

WELCH, J.R.; COIMBRA, C.E. Indigenous fire ecologies, restoration, and territorial sovereignty in the Brazilian Cerrado: The case of two Xavante reserves. Land Use Policy, p. 104055, 2019. Available at: https://doi.org/10.1016/j.landusepol.2019.104055. Access in: 20 Mar. 2020. 